\title{
ANALISIS KEBERMANFAATAN WEBSITE SEKOLAH TINGGI PARIWISATA (STIPAR) TRIATMA JAYA MENGGUNAKAN METODE USABILITY TESTING
}

\author{
Ni Luh Putu Ratih Indriyani1 , *,Gede Rasben Dantes², Kadek Yota Ernanda \\ Aryanto ${ }^{3}$.
}

1 Universitas Pendidikan Ganesha

2 Universitas Pendidikan Ganesha

${ }^{3}$ Universitas Pendidikan Ganesha

\section{Abstrak}

This research is aimed to determine the results of the usability analysis from the website Sekolah Tinggi Pariwisata (STIPAR) Triatma Jaya viewed from the user side as well as knowing the recommendation of website improvement of Sekolah Tinggi Pariwisata (STIPAR) Triatma Jaya from usability aspect. The methods used are Usability Testing of Performance Measurement and Retrospective Think Aloud (RTA) techniques and the dissemination of SUS questionnaires. The results showed that the Sekolah Tinggi Pariwisata (STIPAR) Triatma Jaya still not effective, it is seen from the error or mistake made by users of lecturers and students while doing the task. Statistically website Sekolah Tinggi Pariwisata (STIPAR) Triatma Jaya has been efficient for lecture but not efficient for college students users. For lecturers there are 6 out of 10 tasks that do not have significant time difference, while for college students there are 4 out of 10 tasks that do not have significant time difference. From the aspect of user satisfaction, both lecturers and college students feel still less satisfied using the website of Sekolah Tinggi Pariwisata (STIPAR) Triatma Jaya, this can be seen from the SUS questionnaire scores of lecturers of 63.28 and college students users of 58.44. Based on the analysis result, it can be concluded that the Sekolah Tinggi Pariwisata (STIPAR) Triatma Jaya has not fulfilled the criteria of products that have good usability, because the three aspects (effectiveness, efficiency and user satisfaction) have not been met. Based on the above, the recommendation of Sekolah Tinggi Pariwisata (STIPAR) Triatma Jaya website is focused on adjustment of display, language and term change, feature addition, menu name adjustment, menu structure and menu layout, content addition and menu simplification. Repairs done by making wireframe recommendation page Sekolah Tinggi Pariwisata (STIPAR) Triatma Jaya.
\end{abstract}

\begin{tabular}{lr} 
Keywords: \\
\hline Sekolah & Tinggi \\
Pariwisatar & (STIPAR) \\
Triatma Jaya, usability, & usability testing, website.
\end{tabular}

\section{PENDAHULUAN}

Seiring dengan pesatnya perkembangan teknologi informasi, banyak layanan dan produk yang merupakan aplikasi berbasis web, dimanfaatkan untuk mendukung kegiatan sehari-hari. Pengembangan aplikasi berbasis web haruslah melalui beberapa pedoman kebermanfaatan (usability) untuk memastikan bahwa tujuan website yang dimaksud dapat dicapai. Usability Testing menurut Utama (dalam Utami 2016) merupakan teknik yang digunakan untuk mengevaluasi produk dengan mengujinya langsung pada pengguna. Tujuan utama dari Usability Testing mengacu pada evaluasi produk atau jasa dengan menguji produk atau jasa tersebut kepada pengguna untuk melihat seberapa jauh sistem berfungsi mencakup kesesuaian penggunaan sistem terhadap harapan pengguna, mengidentifikasi permasalahan khusus yang terjadi pada sistem serta untuk mengetahui tingkat efektivitas, efisiensi sebuah produk dan memuaskan dalam ruang lingkup penggunanya.

Usability Testing digunakan untuk mengevaluasi website Sekolah Tinggi Pariwisata (STIPAR) Triatma Jaya dikarenakan adanya beberapa kekurangan yang peneliti temukan saat melakukan observasi ke STIPAR Triatma Jaya antara lain, analisis pada website STIPAR Triatma Jaya sama sekali belum pernah dilakukan. Analisis akan sangat bermanfaat sebagai dasar untuk pengembangan situs web yang telah 
dimiliki. Pengguna, khususnya mahasiswa terlihat sangat jarang mengakses website STIPAR Triatma Jaya. Kurangnya minat pengguna, khususnya mahasiswa dalam mengakses website STIPAR Triatma Jaya menurut pandangan peneliti disebabkan oleh tidak adanya ketertarikan dan keterikatan pengguna dengan website yang digunakan, sehingga pengguna merasa website tidak terlalu penting untuk diakses. Selain itu, dari awal dikembangkan sampai saat ini website STIPAR Triatma Jaya belum pernah dilakukan perbaikan baik dari segi kebutuhan pengguna maupun dari segi teknologi yang digunakan. Perbaikan dari segi kebutuhan pengguna sangat penting dilakukan, sebab tujuan dari dikembangkannya website perguruan tinggi adalah untuk memberikan informasi dan layanan kepada pengguna dengan berbagai cara sesuai dengan apa yang pengguna butuhkan. Sedangkan perbaikan dari segi teknologi yang digunakan akan sangat bermanfaat bagi website tersebut. Perkembangan teknologi yang baru memungkinkan terjadinya interaksi dengan konsep yang lebih mudah dan fleksibel dalam penggunaannya, membuat website lebih mudah dan ringan diakses serta tidak memakan resource yang banyak.

Berdasarkan pemaparan di atas, salah satu cara yang dapat dilakukan untuk meningkatkan kebermanfaatan (usability) website sebuah perguruan tinggi dapat dilakukan dengan menganilisis tingkat kebermanfaatan (usability) pada website tersebut. Oleh karena itu, peneliti ingin melakukan penelitian mengenai Analisis Kebermanfaatan Website Sekolah Tinggi Pariwisata (STIPAR) Triatma Jaya Menggunakan Metode Usability Testing

\section{METODE PENELITIAN}

Jenis penelitian Analisis Kebermanfaatan Website STIPAR Triatma Jaya ini adalah penelitian survey berbasis pengguna sedangkan metodenya adalah deskriptif analitis. Menurut Morisan dalam Utami (2016) metode survey deskriptif berupaya menjelaskan atau mencatat kondisi atau sikap untuk menjelaskan apa yang ada saat ini. Penelitian ini menganalisis secara deskriptif mengenai penggunaan Website STIPAR Triatma Jaya ditinjau dari aspek kebermanfaatannya (usability). Prosedur penelitian yang dilakukan dalam penelitian ini dapat dilihat dalam bentuk diagram alir yang terdapat pada Gambar 1 berikut.

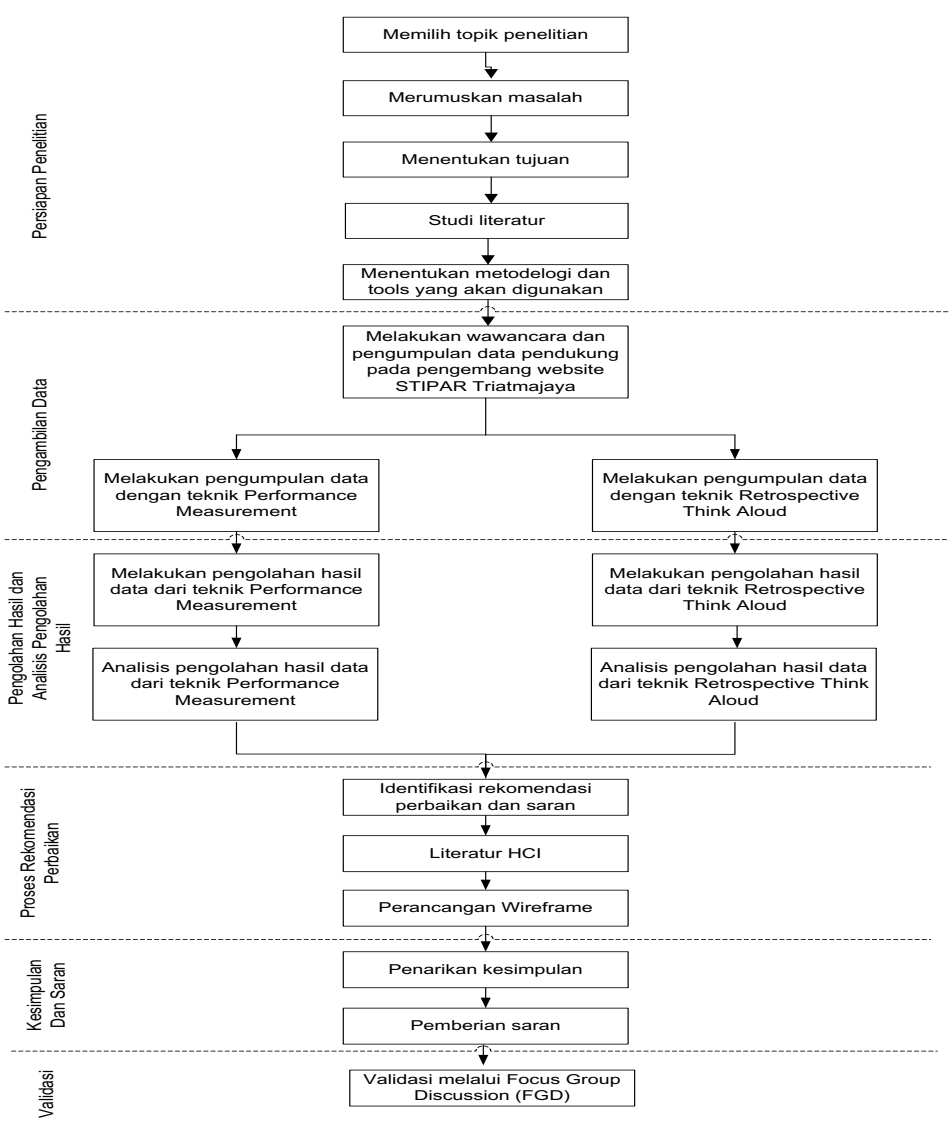

Gambar 1. Tahapan Penelitian 
Populasi dalam penelitian ini adalah dosen dan mahasiswa di STIPAR Triatma Jaya. Jumlah populasi dosen STIPAR Triatma Jaya menurut bagian akademik STIPAR Triatma Jaya sebanyak 31 orang dan jumlah mahasiswa sebanyak 870 orang. Teknik pengambilan sampel yang digunakan dalam penelitian ini adalah teknik Stratified Random Sampling. Total sampel dalam penelitian ini berjumlah 32 responden terdiri atas dosen dan mahasiswa di jurusan yang ada di STIPAR Triatma Jaya, yaitu jurusan D III Manajemen Kepariwisataan, D III Manajemen Perhotelan, dan D IV Manajemen Perhotelan. Sampel tersebut selanjutnya menjadi responden penelitian. Responden dosen sebanyak 16 orang dan responden mahasiswa sebanyak 16 orang, kemudian masing-masing kategori tersebut dikelompokkan menjadi 2 kelompok yaitu kelompok mahir dan kelompok pemula.

Penelitian ini merupakan penelitian yang tujuannya untuk menganalisis sebuah sistem yaitu Website STIPAR Triatma Jaya yang diukur dari aspek kebermanfaatannya (usability) yang mencakup Efektivitas (Effectiveness), Efisiensi (Efficiency) dan Kepuasan Pengguna (Statisfaction). Metode pengumpulan data yang dilakukan dalam penelitian ini diadopsi dari penelitian yang dilakukan sebelumnya oleh Utami (2016). Adapun metode yang dilakuakan ialah wawancara, Performance Measurement, Retrospective Think Aloud (RTA). Dalam penelitian ini, instrumen yang digunakan adalah dalam bentuk wawancara, daftar task skenario, dan kuesioner SUS.

Untuk pengumpulan data kuantitatif dilakukan dengan usability testing teknik Performance Measurement dan menyebarkan kuesioner SUS kepada responden, setelah data didapatkan untuk melihat keefektifan akan dilihat jumlah error yang terjadi pada masing-masing kelompok untuk setiap tugasnya. Untuk mengukur keefisienan Website STIPAR Triatma Jaya akan dilakukan pengolahan secara statistik dengan metode pengolahan yang membandingkan 2 kelompok independen. Untuk membandingkan waktu pengerjaan 2 kelompok yang independen dapat dilakukan pengolahan data statistik menggunakan Mann Whitney U-test. Untuk data kuisioner SUS dilakukan dengan perhitungan kuisioner SUS. Sedangkan data kualitatif didapatkan dengan teknik RTA berupa data tertulis yang peneliti dapatkan dari proses pencatatan yang dilakukan saat responden menyaksikan pemutaran kembali data video yang didapat dari pengambilan data menggunakan teknik Performance Measurement.

Dasar penentuan perbaikan yang dilakukan pada penelitian ini didapat dari hasil usability testing yaitu metode RTA dan juga dari panduan pembuatan user interface halaman web bedasarkan ilmu HCI yang didapat dari literatur.

\section{ANALISIS DAN PEMBAHASAN}

Dalam penelitian ini data yang diperoleh dari proses usability testing berupa data kuantitatif dan kualitatif. Pengumpulan data kuantitatif dilakukan dengan usability testing teknik Performance Measurement dan menyebarkan kuesioner SUS kepada responden. Data yang didapat dari teknik Performance Measurement dan kuesioner SUS tersebut kemudian diolah untuk melihat keefektifan dan kefesienan serta kepuasan pengguna terhadap Website STIPAR Triatma Jaya. Untuk menganalisa keefektifan akan dilihat jumlah error yang terjadi pada masing-masing kelompok untuk setiap tugasnya. Untuk menganalisa keefisienan Website STIPAR Triatma Jaya akan dilakukan pengolahan secara statistik dengan metode pengolahan yang membandingkan 2 kelompok independen. Untuk membandingkan waktu pengerjaan 2 kelompok yang independen dilakukan pengolahan data statistik menggunakan Mann Whitney U-test untuk pengolahan data non-parametrik. Kemudian untuk menganalisa kepuasan pengguna dilakukan dengan menghitung nilai/skor setiap pernyataan. Sedangkan data kualitatif didapat dari teknik Retrospective Think Aloud (RTA). Data yang didapat dari teknik RTA ini berupa kesimpulan saran atau kritik responden dari proses pencatatan yang dilakukan peneliti saat responden menyaksikan pemutaran kembali data video yang didapat dari pengambilan data menggunakan teknik Performance Measurement.

Untuk menganalisis efektivitas Website STIPAR Triatma Jaya dilakukan analisa dengan melihat jumlah error atau kesalahan yang terjadi saat responden meyelesaikan tugas. Adapun persentase error atau kesalahan yang dilakukan responden dosen kelompok pemula pada tugas 9 berjumlah 62.50\%. Data performance measurement menunjukkan bahwa responden yang melakukan error atau kesalahan adalah responden dengan kode DP09, DP10, DP11, DP12 dan DP14. Pada Tugas 9 penyebab utama error atau kesalahan yang dilakukan responden yaitu kebingungan saat akan memilih menu yang akan diklik, dikarenakan menu yang tersedia dan tampil di halaman responden cukup banyak, kemudian responden tidak menuntaskan tugas yang diberikan sehingga responden dianggap sebagai error atau kesalahan serta kurangnya minat responden untuk menggunakan sistem.

Adapun persentase error atau kesalahan yang dilakukan responden mahasiswa kelompok pemula pada tugas 2 berjumlah $12.50 \%$ dan pada tugas 9 berjumlah 25\%. Data performance measurement menunjukkan bahwa responden yang melakukan error atau kesalahan adalah responden dengan kode 
MP15 pada proses pengerjaan tugas 2 serta MP09 dan MP16 pada proses pengerjaan tugas 9. Pada Tugas 2 penyebab utama error atau kesalahan yang dilakukan responden yaitu responden tidak membaca tugas 2, sehingga tugas 2 terlewati oleh responden, sedangkan pada Tugas 9 penyebab utama error atau kesalahan yang dilakukan responden yaitu responden terfokus pada bagian Informasi Pengguna saja dan tidak mencari pada submenu, sehingga tidak dapat menyelesaikan tugas yang diberikan.

Berikut merupakan output rank dari hasil pengujian statistik dengan Mann Whitney U-test pada waktu pengerjaan tugas responden dosen kelompok mahir (1) dengan kelompok pemula (2). Hasil pengujian tersebut tersedia pada Tabel 1 dibawah ini.

Tabel 1. Output Rank Pengolahan Data Dosen

\begin{tabular}{|c|c|c|c|c|}
\hline & Kelompok & $\mathrm{N}$ & $\begin{array}{l}\text { Mean } \\
\text { Rank }\end{array}$ & $\begin{array}{l}\text { Sum of } \\
\text { Ranks }\end{array}$ \\
\hline \multirow[t]{3}{*}{ Tugas_1 } & Mahir & 8 & 5.75 & 46.00 \\
\hline & Pemula & 8 & 11.25 & 90.00 \\
\hline & Total & 16 & & \\
\hline \multirow[t]{3}{*}{ Tugas_2 } & Mahir & 8 & 5.12 & 41.00 \\
\hline & Pemula & 8 & 11.88 & 95.00 \\
\hline & Total & 16 & & \\
\hline \multirow[t]{3}{*}{ Tugas_3 } & Mahir & 8 & 7.62 & 61.00 \\
\hline & Pemula & 8 & 9.38 & 75.00 \\
\hline & Total & 16 & & \\
\hline \multirow[t]{3}{*}{ Tugas_4 } & Mahir & 8 & 5.00 & 40.00 \\
\hline & Pemula & 8 & 12.00 & 96.00 \\
\hline & Total & 16 & & \\
\hline \multirow[t]{3}{*}{ Tugas_5 } & Mahir & 8 & 9.00 & 72.00 \\
\hline & Pemula & 8 & 8.00 & 64.00 \\
\hline & Total & 16 & & \\
\hline \multirow[t]{3}{*}{ Tugas_6 } & Mahir & 8 & 6.62 & 53.00 \\
\hline & Pemula & 8 & 10.38 & 83.00 \\
\hline & Total & 16 & & \\
\hline \multirow[t]{3}{*}{ Tugas_7 } & Mahir & 8 & 7.50 & 60.00 \\
\hline & Pemula & 8 & 9.50 & 76.00 \\
\hline & Total & 16 & & \\
\hline Tugas_8 & Mahir & 8 & 6.88 & 55.00 \\
\hline
\end{tabular}




\begin{tabular}{ccccc}
\hline & & & Mean & Sum of \\
& Kelompok & $\mathrm{N}$ & Rank & Ranks \\
\hline & Pemula & 8 & 10.12 & 81.00 \\
Tugas_9 & Mahir & 8 & 4.75 & 38.00 \\
& Pemula & 3 & 9.33 & 28.00 \\
Tugas_10 & Total & 11 & & \\
& Mahir & 8 & 10.50 & 84.00 \\
& Pemula & 8 & 6.50 & 52.00 \\
& & & & \\
\hline & Total & 16 & & \\
\hline
\end{tabular}

Tabel 1 menunjukkan mean rank untuk pengerjaan tugas 1, tugas 2, tugas 3, tugas 4, tugas 6, tugas 7 , tugas 8 dan tugas 9 pada responden kelompok mahir adalah lebih kecil dari kelompok pemula. Dari data diketahui bahwa pengerjaan tugas 1, tugas 2, tugas 3, tugas 4, tugas 6, tugas 7, tugas 8 dan tugas 9 lebih cepat dari responden pemula, hal tersebut disebabkan oleh halaman website Sekolah Tinggi Pariwisata (STIPAR) Triatma Jaya yang hanya mudah digunakan oleh pengguna yang telah terbiasa atau sudah sering mengakses halaman website Sekolah Tinggi Pariwisata (STIPAR) Triatma Jaya.

Output Test Statistik Pengolahan Data Dosen menunjukkan bahwa nilai $p$-value dari tugas 1, tugas 2, tugas 3 , tugas 4 , tugas 5 , tugas 6 , tugas 7 , tugas 8 , tugas 9 dan tugas 10 bernilai 0.021 untuk tugas $1,0.005$ untuk tugas 2, 0.462 untuk tugas 3, 0.003 untuk tugas 4, 0.647 untuk tugas 5, 0.115 untuk tugas 6, 0.401 untuk tugas 7, 0.172 untuk tugas 8, 0.041 untuk tugas 9 dan 0.093 untuk tugas 10. Untuk menyimpulkan pengolahan data ini, setiap $p$-value masing-masing perbandingan pada setiap tugas akan dibandingkan dengan nilai $\alpha$ yang bernilai 0.05 . Apabila nilai $p$-value lebih besar dari 0.05 maka keputusan yang diambil adalah tidak menolak H0.

Berbedoman pada hasil penelitian yang dilakukan sebelumnya oleh Utami (2016) tentang Evaluasi Usability Pada E-Learning Universitas Pendidikan Ganesha dengan Metode Usability Testing yang menyatakan untuk menyimpulkan pengolahan data, setiap $p$-value masing-masing perbandingan pada setiap tugas akan dibandingkan dengan nilai $\alpha$ yang bernilai 0.05 . Apabila nilai $p$-value lebih besar dari 0.05 maka keputusan yang diambil adalah tidak menolak H0 sedangkan apabila nilai $p$-value lebih kecil dari 0.05 maka keputusan yang diambil adalah menolak H0. Oleh karena itu, dapat ditarik kesimpulan bahwa secara statistik dari 6 tugas dapat dinyatakan tidak ada perbedaan yang signifikan, dan terdapat 4 tugas yang memiliki perbedaan yang signifikan waktu pengerjaan tugas responden dosen kelompok mahir dan kelompok pemula. Persentase tugas yang tidak ada perbedaan yang signifikan waktu pengerjaannya lebih besar daripada tugas yang memiliki perbedaan yang signifikan waktu pengerjaannya. Maka dari itu diputuskan bahwa halaman website Sekolah Tinggi Pariwisata (STIPAR) Triatma Jaya dari segi pengguna dosen sudah efisien.

Pada Tabel 2 tersedia output rank dari hasil pengujian statistik dengan Mann Whitney U-test pada waktu pengerjaan tugas responden mahasiswa kelompok mahir (1) dengan kelompok pemula (2).

Tabel 2. Output Rank Pengolahan Data Mahasiswa

\begin{tabular}{ccccc}
\hline & Kelompok & $\mathrm{N}$ & $\begin{array}{c}\text { Mean } \\
\text { Rank }\end{array}$ & $\begin{array}{c}\text { Sum of } \\
\text { Ranks }\end{array}$ \\
\hline \multirow{2}{*}{ Tugas_1 } & Mahir & 8 & 4.50 & 36.00 \\
& Pemula & 8 & 12.50 & 100.00 \\
\hline
\end{tabular}




\begin{tabular}{|c|c|c|c|c|}
\hline & Kelompok & $\mathrm{N}$ & $\begin{array}{l}\text { Mean } \\
\text { Rank }\end{array}$ & $\begin{array}{c}\text { Sum of } \\
\text { Ranks }\end{array}$ \\
\hline & Total & 16 & & \\
\hline \multirow[t]{3}{*}{ Tugas_2 } & Mahir & 8 & 5.00 & 40.00 \\
\hline & Pemula & 7 & 11.43 & 80.00 \\
\hline & Total & 15 & & \\
\hline \multirow[t]{3}{*}{ Tugas_3 } & Mahir & 8 & 5.12 & 41.00 \\
\hline & Pemula & 8 & 11.88 & 95.00 \\
\hline & Total & 16 & & \\
\hline \multirow[t]{3}{*}{ Tugas_4 } & Mahir & 8 & 8.00 & 64.00 \\
\hline & Pemula & 8 & 9.00 & 72.00 \\
\hline & Total & 16 & & \\
\hline \multirow[t]{3}{*}{ Tugas_5 } & Mahir & 8 & 6.12 & 49.00 \\
\hline & Pemula & 8 & 10.88 & 87.00 \\
\hline & Total & 16 & & \\
\hline \multirow[t]{3}{*}{ Tugas_6 } & Mahir & 8 & 5.12 & 41.00 \\
\hline & Pemula & 8 & 11.88 & 95.00 \\
\hline & Total & 16 & & \\
\hline \multirow[t]{3}{*}{ Tugas_7 } & Mahir & 8 & 8.88 & 71.00 \\
\hline & Pemula & 8 & 8.12 & 65.00 \\
\hline & Total & 16 & & \\
\hline \multirow[t]{3}{*}{ Tugas_8 } & Mahir & 8 & 6.88 & 55.00 \\
\hline & Pemula & 8 & 10.12 & 81.00 \\
\hline & Total & 16 & & \\
\hline \multirow[t]{3}{*}{ Tugas_9 } & Mahir & 8 & 4.75 & 38.00 \\
\hline & Pemula & 6 & 11.17 & 67.00 \\
\hline & Total & 14 & & \\
\hline \multirow{2}{*}{$\begin{array}{c}\text { Tugas_1 } \\
0\end{array}$} & Mahir & 8 & 8.38 & 67.00 \\
\hline & Pemula & 8 & 8.62 & 69.00 \\
\hline
\end{tabular}




\begin{tabular}{cccc}
\hline & & Mean & Sum of \\
Kelompok & $\mathrm{N}$ & Rank & Ranks \\
\hline Total & 16 & & \\
\hline
\end{tabular}

Tabel 2 menunjukkan mean rank untuk pengerjaan tugas 1, tugas 2, tugas 3, tugas 4, tugas 5, tugas 6 , tugas 8 , tugas 9 dan tugas 10 pada responden kelompok mahir adalah lebih kecil dari kelompok pemula. Dari data diketahui bahwa pengerjaan tugas 1 , tugas 2, tugas 3 , tugas 4 , tugas 5 , tugas 6 , tugas 8 , tugas 9 dan tugas 10 lebih cepat dari responden pemula, hal tersebut disebabkan oleh halaman website Sekolah Tinggi Pariwisata (STIPAR) Triatma Jaya yang hanya mudah digunakan oleh pengguna yang telah terbiasa atau sudah sering mengakses halaman website Sekolah Tinggi Pariwisata (STIPAR) Triatma Jaya.

Output Test Statistik Pengolahan Data Mahasiswa menunjukkan bahwa nilai p-value dari tugas 1, tugas 2 , tugas 3 , tugas 4 , tugas 5 , tugas 6 , tugas 7 , tugas 8 , tugas 9 dan tugas 10 bernilai 0.001 untuk tugas $1,0.005$ untuk tugas $2,0.005$ untuk tugas $3,0.647$ untuk tugas $4,0.046$ untuk tugas $5,0.005$ untuk tugas 6 , 0.753 untuk tugas $7,0.172$ untuk tugas $8,0.005$ untuk tugas 9 dan 0.916 untuk tugas 10 . Untuk menyimpulkan pengolahan data ini, setiap p-value masing-masing perbandingan pada setiap tugas akan dibandingkan dengan nilai $\alpha$ yang bernilai 0.05. Apabila nilai $p$-value lebih besar dari 0.05 maka keputusan yang diambil adalah tidak menolak $\mathrm{HO}$.

Berbedoman pada hasil penelitian yang dilakukan sebelumnya oleh Utami (2016) tentang Evaluasi Usability Pada E-Learning Universitas Pendidikan Ganesha dengan Metode Usability Testing yang menyatakan untuk menyimpulkan pengolahan data, setiap $p$-value masing-masing perbandingan pada setiap tugas akan dibandingkan dengan nilai $\alpha$ yang bernilai 0.05 . Apabila nilai $p$-value lebih besar dari 0.05 maka keputusan yang diambil adalah tidak menolak H0 sedangkan apabila nilai $p$-value lebih kecil dari 0.05 maka keputusan yang diambil adalah menolak H0. Oleh karena itu, dapat ditarik kesimpulan bahwa secara statistik dari 4 tugas dapat dinyatakan tidak ada perbedaan yang signifikan, dan terdapat 6 tugas yang memiliki perbedaan yang signifikan waktu pengerjaan tugas responden dosen kelompok mahir dan kelompok pemula. Persentase tugas yang tidak ada perbedaan yang signifikan waktu pengerjaannya lebih kecil daripada tugas yang memiliki perbedaan yang signifikan waktu pengerjaannya. Maka dari itu diputuskan bahwa halaman website Sekolah Tinggi Pariwisata (STIPAR) Triatma Jaya dari segi pengguna mahasiswa belum efisien.

Hasil dari analisis nilai skor kepuasan pengguna dengan menggunakan kuesioner SUS yang dilakukan responden setelah selesai berinteraksi dengan Website STIPAR Triatma Jaya dapat dilihat pada Gambar 1 di bawah ini.

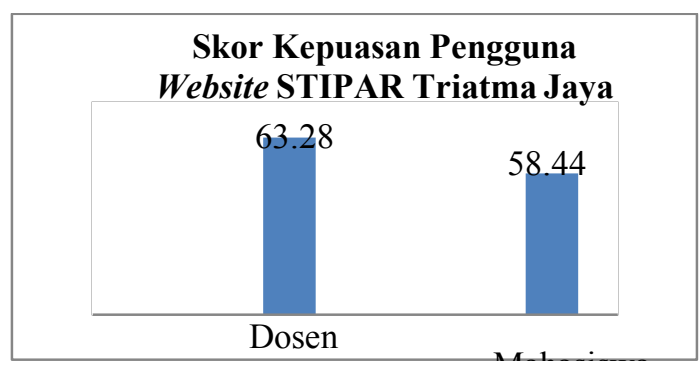

Gambar 1 Skor Kepuasan Pengguna Website STIPAR Triatma Jaya

Dari gambar di atas adapun nilai skor untuk responden dosen sebesar 63,28. Hal ini berarti nilai skor yang diperoleh dari responden dosen lebih kecil dari nilai skor standar kuesioner SUS yaitu 68, sehingga dapat dikatakan bahwa, responden dosen kurang puas dalam menggunakan website STIPAR Triatma Jaya. Sedangkan hasil analisis untuk responden mahasiswa sebesar 58,44. Hal ini juga berarti nilai skor yang diperoleh dari responden mahasiswa lebih kecil dari nilai skor standar kuesioner SUS yaitu 68, sehingga dapat dikatakan bahwa, responden mahasiswa kurang puas dalam menggunakan website STIPAR Triatma Jaya.

Rekomendasi perbaikan dilakukan dengan membuat wireframe, dimana dasar dari pengembangan rekomendasi perbaikan adalah panduan $\mathrm{HCI}$ dan hasil data usabilitity testing. Berdasarkan hasil Performance Measurement dan Retrospective Think Aloud (RTA), rekomendasi perbaikan dalam penelitian ini akan difokuskan untuk penyesuaian tampilan, perubahan bahasa dan istilah, penambahan fitur, 
penyesuaian nama menu, susunan menu dan tata letak menu, penambahan konten serta penyederhanaan menu. Berikut adalah halaman website STIPAR Triatma Jaya hasil rekomendasi perbaikan.

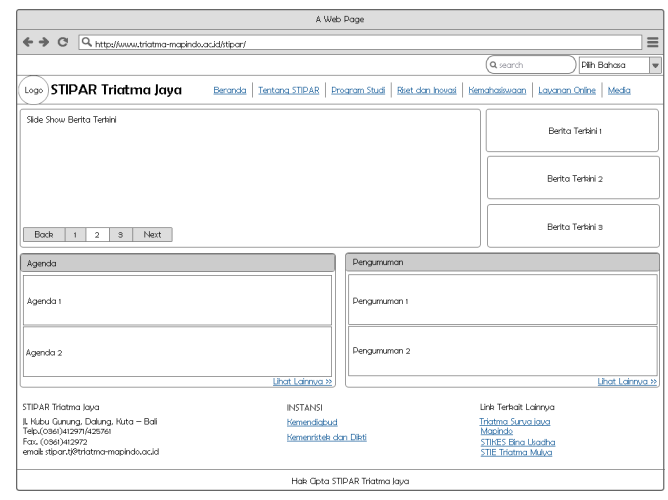

Gambar 2 Wireframe Rekomendasi Perbaikan Halaman Utama Website STIPAR Triatma Jaya

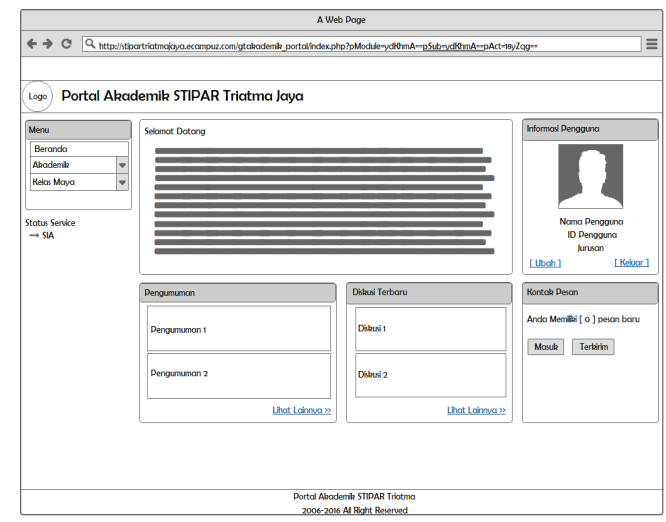

Gambar 3 Wireframe Rekomendasi Rekomendasi Perbaikan Halaman SIMAK

\section{KESIMPULAN}

Berdasarkan Berdasarkan hasil penelitian dan pembahasan yang disajikan pada bab sebelumnya maka dapat ditarik simpulan bahwa: a) Efektivitas, hasil yang didapat dari penelitian ini menunjukkan bahwa halaman website Sekolah Tinggi Pariwisata (STIPAR) Triatma Jaya secara umum masih belum efektif, karena terjadi error atau kesalahan dalam pengerjaan tugas yang dilakukan oleh responden dosen dan mahasiswa, b) Efisiensi, secara statistik hasil yang didapat menunjukkan bahwa untuk responden dosen tidak terdapat perbedaan waktu yang signifikan pengerjaan tugas antara pengguna kelompok mahir dengan kelompok pemula, hal ini dapat dilihat dari waktu pengerjaan tugas kelompok dosen, terdapat 6 dari 10 tugas yang dikerjakan tidak memiliki perbedaan waktu pengerjaan yang signifikan. Sedangkan untuk responden mahasiswa terdapat perbedaan waktu pengerjaan tugas antara pengguna kelompok mahir dengan kelompok pemula, hal ini dapat dilihat dari waktu pengerjaan tugas kelompok mahasiswa, terdapat 4 dari 10 tugas yang dikerjakan tidak memiliki perbedaan waktu pengerjaan yang signifikan. Dari data tersebut dapat disimpulkan bahwa halaman website Sekolah Tinggi Pariwisata (STIPAR) Triatma Jaya sudah efisien bagi pengguna dosen namun belum efisien bagi pengguna mahasiswa, c) Kepuasan Pengguna, dari hasil yang didapat pada penelitian ini diketahui bahwa skor yang diperoleh baik dari responden dosen maupun responden mahasiswa kurang dari 68. Untuk responden dosen adapun skor yang didapat sebesar 63,28 sehingga responden dosen dikatakan kurang puas menggunakan website Sekolah Tinggi Pariwisata (STIPAR) Triatma Jaya, hal ini dikarenakan responden dosen masih memerlukan bantuan orang lain ketika menggunakan website Sekolah Tinggi Pariwisata (STIPAR) Triatma Jaya serta responden dosen menemukan fitur yang sulit untuk digunakan. Untuk responden mahasiswa adapun skor yang didapat sebesar 58.44 sehingga responden mahasiswa dikatakan kurang puas menggunakan website Sekolah Tinggi Pariwisata (STIPAR) Triatma Jaya, hal ini dikarenakan responden mahasiswa merasa website Sekolah Tinggi Pariwisata (STIPAR) Triatma Jaya tidak terlalu 
kompleks serta responden mahasiswa merasa banyak tampilan yang tidak konsisten pada website Sekolah Tinggi Pariwisata (STIPAR) Triatma Jaya.

Berdasarkan hasil penelitian, pembahasan dan Berdasarkan hasil penelitian dan kesimpulan yang dikemukan sebelumnya, dapat disarankan beberapa hal sebagai berikut: 1) Bagi STIPAR Triatma Jaya: a) Sebaiknya melakukan sosialisasi kepada pengguna dalam hal ini ialah mahasiswa dan dosen tentang pemanfaatan website Sekolah Tinggi Pariwisata (STIPAR) Triatma Jaya khususnya dalam menunjang proses belajar mengajar dan penyebaran informasi agar dapat membantu pengguna yang kurang memahami penggunaan website Sekolah Tinggi Pariwisata (STIPAR) Triatma Jaya, b) Hendaknya website STIPAR Triatma Jaya dikelola dengan baik dengan cara menugaskan salah satu staff/pegawai Sekolah Tinggi Pariwisata (STIPAR) Triatma Jaya untuk mengelola website, sehingga informasi yang terdapat pada website dapat diperbarui setiap saat, c) Untuk meningkatkan kebermanfaatan (usability) website Sekolah Tinggi Pariwisata (STIPAR) Triatma Jaya, hendaknya dilakukan analisis website dalam kurun waktu 5 tahun sekali, sehingga website yang ada sesuai dengan kebutuhan pengguna dan perkembangan teknologi terkini.

2) Bagi Pengembang: a) Sebaiknya dilakukan penyesuaian design/tampilan website Sekolah Tinggi Pariwisata (STIPAR) Triatma Jaya agar terlihat menarik, b) Hendaknya secara rutin dan berkala melakukan pengecekan terhadap website Sekolah Tinggi Pariwisata (STIPAR) Triatma Jaya, sebab masih terdapat link error pada website, sehingga menyulitkan pengguna dalam mengakses informasi yang diperlukan. 3) Bagi Pengguna, hendaknya selalu memberikan saran/masukan yang positif demi pengembangan website Sekolah Tinggi Pariwisata (STIPAR) Triatma Jaya, sehingga secara langsung akan berdampak terhadap kepuasan pengguna itu sendiri dalam memanfaatkan fasilitas yang diberikan website Sekolah Tinggi Pariwisata (STIPAR) Triatma Jaya, 4) Bagi Peneliti, disarankan untuk melakukan penelitian mengenai analisis kebermanfaatan (usability) dengan menggunakan metode lain, sehingga didapatkan hasil penelitian yang lebih beragam dan dapat diketahui secara lebih luas tentang metode-metode yang digunakan dalam menganalisis sebuah website.

\section{DAFTAR PUSTAKA}

guide to Usability Testing, John Wiley \& Sons.

International Organization for Standardization, (1998), ISO 9241-11: Guidance on Usability.

Istiana, Purwani. 2011. Evaluasi Usability Situs Web Perpustakaan. http://digilib.undip.ac.id/ v2/2012/05/14/evaluasi-usability-situs-web-perpustakaan/. Diakses tgl 16 Maret 2016.

JeffAxup., (2004) Usability Professionals Association, About Usability, Available: http://www.upassoc.org, diakses pada bulan Juni 2012.

Junus, Inas Sofiyah, dkk. 2015. "Usability Evaluation of the Student Centered e-Learning Environment". Jurnal International Review of Research in Open and Distributed Learning, Vol.1 6, No. 4.

Nugroho, Eko. 2009. Desain Situs Reader Friendly. Yogyakarta : Andi Offset.

Rahadi, Dedi Rianto. 2014. "Pengukuran Usability Sistem Menggunakan Use Questionnaire Pada Aplikasi Android”. Jurnal Sistem Informasi (JSI), Vol. 6, No. 1, ISSN: 2355-4614

Setia, Lutfiyah Dwi. 2012. Evaluasi Usability Untuk Mengetahui Akseptabilitas Aplikasi Berbasis Web. http://lib.umpo.ac.id/files/204c2-jurnal-Juni-2012.pdf. Diakses tanggal 16 Maret 2016.

Utama, Satria. 2011. Perbaikan User Interface Halaman Internet Banking dengan Metode Usability Testing. Skripsi (Tidak Diterbitkan). Program Teknik Industri, FT, UI.

Utami, Nengah Widya. 2016. Evaluasi Usability Pada E-Learning Universitas Pendidikan Ganesha Dengan Metode Usability Testing. Skripsi (Tidak Diterbitkan). Jurusan Pendidikan Teknik Informatika, FTK, Undiksha. 